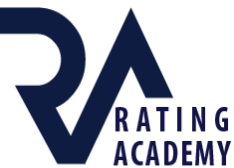

Journal of Arts

Cilt / Volume 2, Sayı / Issue 3, 2019, pp. 169-180

E - ISSN: 2636-7718

URL: https://ratingacademy.com.tr/ojs/index.php/arts/index

DOİ: https://doi.org/10.31566/arts.2.012

Araştırma Makalesi / Research Article

\title{
ORTAKLAR KÖY ENSTITÜSÜNDE MODERN MİMARLIĞIN İZLERİ
}

TRACES OF MODERN ARCHITECTURE IN THE VILLAGE INSTITUTE

\author{
Sıdıka ÇETİN * \& Gamze KIRAN ** \\ * Doç. Dr., Süleyman Demirel Üniversitesi, Mimarlık Fakültesi Mimarlık Bölümü, TÜRKIYE, \\ E-mail: scetin71@gmail.com \\ ** Doktora Öğrencisi, Akdeniz Üniversitesi, Fen Bilimleri Enstitüsü, TÜRKIYE, \\ E-mail: gamzekiran@windowslive.com
}

Geliş Tarihi: 9 Temmuz 2019; Kabul Tarihi: 29 Temmuz 2019

Received: 9 July 2019; Accepted: 29 July 2019

\begin{abstract}
$\ddot{O Z Z E T}$
Köy enstitüleri, Türkiye Cumhuriyeti'nin modernleşme sürecinde kir ile kent arasindaki dengeyi eşitlemek amacıyla kurulmuş özgün ĕ̆itim sistemine sahip kamusal kuruluşlardır. Türkiye'nin farklı bölgelerinde açılmış olan toplam 21 adet enstitüden biri de Aydın'a $30 \mathrm{~km}$. uzaklıkta yer alan Ortaklar Köy Enstitüsüdür. 1944 yılında temeli atılan enstitü, çevredeki tek enstitü olması nedeniyle zamanla eklenen yeni derslikler ve binalarla genişletilmiş ve yaklaşı 30 adet yapıyı içeren bir yerleşke halini almıştır. Farklı işlevlere hizmet eden yapıların yerleşme düzeninde ve mimari karakterlerinde dönem ideolojisinin izleri de mevcuttur. Yerleşke vaziyetinde cadde genişliğinde rasyonel aksin iki yanına sıralanmış binalardan oluşan bir düzen hâkimdir. Geometrik formların esas alındığı tasarımlarda yarım daire formunun ve uzun yatay şerit pencerelerin kullanımı modernist akımın mimari dilini yansitmaktadır. Sahip olduğu doğal çevresi, yerleşim biçimi ve mimarlık özellikleriyle Cumhuriyet dönemini yansitan Enstitü alanına değer katmaktadır. Bu çalışmada modernist felsefeye uygun olarak inşa edilen Ortaklar Köy Enstitüsüne ait yapılar, mimari açıdan incelenecektir.
\end{abstract}

Anahtar Kelimeler: Köy Enstitüleri, Ortaklar Köy Enstitüsü, Modern Mimarlı, Mualla Eyüboğlu Anhegger

\section{ABSTRACT}

Village institutes are public institutions that have an original education system established to equalize the balance between rural and city in the modernization process of the Republic of Turkey. The Ortaklar Village Institute that $30 \mathrm{~km}$ from the Aydin is the one of a total of 21 institutes have been opened in different regions of Turkey. The foundation of the institute was laid in 1944. Due to the fact that it is the only institute in the vicinity, it has been expanded with new classrooms and buildings added over time and has become a campus with about 30 buildings.. There are traces of period ideology in the layout and architectural characteristics of the buildings that serve different functions. In the site plan a layout consisting of buildings on both sides of the rational axis is dominant. In the designs based on geometric forms, the use of semicircle form and long horizontal strip windows reflect the architectural 
language of the modernist movement. The institte that reflecting the Republican period adds value to archtitecture with its natural environment, settlement style and architectural features. In this study, the structures belonging to the Ortaklar Village Institute, which was built in accordance with the modernist philosophy, will be examined in terms of architecture.

Key Words: Village Institutes, Ortaklar Village Institute, Modern Architecture, Mualla Eyüboğlu Anhegger

\section{GíRiş}

Köy enstitüleri 1940'ların zorlu şartlarında, sosyal ve ekonomik kalkınmayı sağlayacak yeni bir eğitim modelidir. Enstitüler ile temelde köy okulları için öğretmen yetiştirmenin ötesinde köyün kalkınması için köylüye liderlik ederek atandığı köylerde halkı bilinçlendirecek, eğitimi, tarımı geliştirecek, kırsaldaki toplumsal kalkınmayı -modernleşmeyi- gerçekleştirecek öğretmenlerin yetiştirilmesi hedeflenmiştir (Yılmaz ve Akandere, 2018: 278). Bu nedenle enstitünün eğitim programı içinde teorik derslerin yanında uygulamalı eğitim de verilmiş ve üretimi ön planda tutan bir model geliştirilmiştir. Köy enstitülerinde üretimin içinde eğitim ile toplumun aydınlanması düşüncesi, temel hedeftir. Bu bakımdan Köy Enstitülerinin pedagojik anlayış1 ve eğitim yöntemleri Bauhaus düşüncesi ile benzerlik göstermektedir. Her iki yaklaşım da iş içinde eğitimi esas alır. Enstitü için gerekli olan her şey öğrencilerin gücü ile gerçekleştirilecektir. Kitabi bilgi yerine uygulamaya önem veren, düşünen, aydın insanların yetiştirilmesi öncelikli hedeftir. Eğitimde temel bakış açısı her ikisi için 'öğrenmeyi öğretmek' olarak tanımlanabilir (Atlıhan, 2009:457).

Bauhaus düşüncesinde Vorkurs'un (ön program, giriş programı, basic design) temel amacı kişinin konvansiyonel düşünce kalıplarını kırarak özgür kalmasını sağlamaktır. Bu, kişinin kendi olanaklarını, sınırlarını, sorumluluklarını görmesine yardımcı olacak kişisel deneyimler ve keşifler için bireyin önünü açan bir düşünce biçimidir (Aközer, 2009:113). Bauhaus çoğu kere bir okul, bir pedagoji, avangard bir akım, bir estetik, bir stil vs olarak ele alınır. Oysa bunların çok ötesinde bir kavrayış, anlayış ve anlamlandırma stilidir. Modernleşmenin dayattığı toplumsal örgütlenmenin gerçekleştirilmesi için bir dönüşüm politikasıdır. Toplumun bir ulus olarak yapılanmasının gerektirdiği bir yurttaş eğitimi projesidir. Uygulamalı ve güzel sanatların kaynaştırılmasından beklenen toplumsal birlik ve kalkınmadır. Toplumsal iş bölümünün, üretimin ve iş gücünün rasyonel örgütlenmesini öngörür. $\mathrm{Bu}$ doktrin gücünü ve estetiğini makinelerde süregelen teknolojide arar (Artun, 2009:193-194). Bauhaus insan faktörünün seri üretimden önemli görüldüğü, tasarım sürecinin tümünün yaşanıp gözlenebildiği pedagojik bir düşünce modelini savunmaktadır. Bu model, yaratıcılık ile tekniği, estetik ile aklı devrimcilik ile yapıcılığı bir araya getirmesi nedeniyle kendilerine yeni bir model kurmaya çalışan Cumhuriyet aydınlarına sağlıklı bir modernite önermektedir. $\mathrm{Bu}$ anlamda Avrupa'daki modernist akımlar içinde Cumhuriyet aydınının kendisini en yakın hissettiği modeldir denilebilir (Köksal, 2009: 254).

Cumhuriyetin ilanından sonra Cumhuriyet ideolojisi ile tutarlı olarak sanat ve zanaat ilişkisini güçlendiren bir eğitim anlayışı ilk olarak Gazi Eğitim Enstitüsü Resim-İş̧ Bölümü’nde hayata geçirilmiştir. Okulun müfredatı 1919 yılında kurulan Bauhaus okulunun amaçlarıyla da örtüşmektedir. Mimarlık alanında ülkemizdeki ilk uygulama 1930'lu yıllarda İstanbul Devlet Güzel Sanatlar Akademisi Mimarlık Bölümü'nde denenir. Kurumun başına getirilen Ernst Egli, daha sonra da Burno Taut, Bauhaus ilkelerini benimsemiş yabancı eğitimcilerdir. Her ikisi de sanatın topluma mal edilmesi, işlevsel hale getirilmesi ve Türkiye'ye geldikten sonra da Cumhuriyet ideallerine hizmet etmesi konusunda çaba harcamışlardır. Mualla Eyüboğlu Anhegger ${ }^{1}$ de Akademide bu anlayışın hâkim olduğu bir dönemde öğrenim görmüştür. 1942- 
1947 yılları arasında Hasanoğlan Köy Enstitüsü'nde Yapı Kolu Başkanı olarak görev yapan Anhegger, bu süreçte Aydın Ortaklar Köy Enstitüsünün vaziyet planını hazırlamış, resim müzik atölyesi ile derslik planını çizerek uygulamasında bulunmuştur. Bu bildiride kübik özellikleri ile Enstitü bünyesindeki diğer yapılardan bariz şekilde ayırt edilebilen bu yapılar özelinde Ortaklar Köy Enstitüsünde modern mimarinin izleri aranacaktır. Modernleşmenin somut bir göstergesi olarak ifade edilen mimari yapılar, dönemin özelliklerini yansıtması bakımından önemli görülürler. Modernin kırsalda nasıl yorumlandığını anlamak açısından bu çalışmanın da literatüre bir katkı sağlayacağı umulmaktadır.

\section{ENSTITÜLERİN KURULUŞU VE MIMMARLIK KAPSAMINDA ELE ALINIŞI}

Köy enstitüleri fikri hayata geçirilmeden kapsamlı bir ön hazırlık süreci geçirmiştir. Enstitüdeki eğitimin nasıl olacağı, kimlerin eğitim vereceği, nerede kurulacağ1, nasıl inşa edileceği, ulaşımın nasıl sağlanacağı gibi konulara getirilen çözümlerle gelişerek nihai halini almıştır. Bu noktada karşımıza çıkan önemli isimlerden biri de köy enstitüsü denildiğinde akla ilk gelen kişi olan İsmail Hakkı Tonguç’tur. Enstitülerin kuruluş sürecinde emek verdiği konulardan biri de enstitülerin temeli sayılabilecek Köy Eğitmenleri Kurslarının ve sonrasında Köy Öğretmen Okulları'nın açılmasıdır. 1936 yılında açılan Köy Eğitmen Kurslarında verilen 6 aylık kurs ile köyler için eğitmenler yetiştirilmiştir. Daha sonra 1937 yılında Eskişehir Çifteler ve İzmir Kızılçullu'da 1938'de Edirne Kepirtepe ve 1939'da Kastamonu Gölköy'de olmak üzere dört adet Köy Öğretmen Okulu açılmış ve eğitim süresi üç yıla çıkarılmıştır. Tüm bu gelişmeler Köy Enstitülerinin kuruluşundaki ön etapları oluşturmaktadır. 1940 yılında 3803 sayılı yasanın "Milli Eğitim Bakanlığınca Köy Enstitülerinin açılması' kararıyla Köy Öğretmen Okulları Köy Enstitülerine çevrilir ve o yıl içerisinde on tane daha enstitü kurulmuştur. 1948 yılında ise ülke geneline yayılan enstitü sayısı yirmi bire yükselmiştir.

Enstitülerin kuruluşundaki mimarlık alanında değerli olan noktalardan biri Milli Eğitim Bakanlığınca açılan ulusal çapta düzenlenen mimari proje yarışmalarıdır. Yarışma şartnamesinde enstitülerin vaziyet planlamasında ve avan projelerinin oluşturulmasında mimarların yükümlü oldukları maddeler ayrıntılı biçimde açıklanmıştır. Genel olarak her Enstitünün ortak temel birimleri şöyle saptanmıştır: Yatakhaneler, yemekhane-mutfak, çamaşırhane-banyo, Açıkhava yıkanma muslukları, sahra tuvaletleri, revir, fırın, kooperatif, ahır, ağıl, tavla, kümes, arılık, balıkhane vb, su deposu ve havuz, çeşitli depolar, elektrik santrali, bağ bahçe, tarla, fidanlık, koruluk, çiçeklik, çeşitli tarım alanları vb, yönetim odası, öğretmen evleri, derslikler, kitaplık, laboratuvar, işlikler, müzik, tiyatro ve toplantı salonu, spor alanları, uygulama alanları, çocuk bahçesi (Türkoğlu, 2000: 202). Bu fonksiyonların bazıları enstitülerin bölgesine göre değişiklik gösterebilmektedir. Örneğin kimi enstitülerde kuşlar binası, balıkçılık malzemeleri deposu gibi farklı ihtiyaçlara karşılık inşa edilen yapılar ile açık hava tiyatrosu, müze ve sergi binası gibi sosyo-kültürel yapılar da görmek mümkündür. Açık mekânların düzenlenmesinde ise yeşil alanlar, tarım faaliyetlerinin gerçekleştirebileceği bahçeler, açık spor alanları, tören alanı şeklinde sıralanabilir. Tüm bu mekânların örgütlenme biçimi de yarışma şartnamesinde belirtilen konulardan birisidir. Açık alanların ve yapıların yakın ilişki içinde olmasıyla günlük yaşantı ve eğitimin bir arada devam etmesi öngörülmüştür. $\mathrm{Bu}$ örüntüyü güçlendiren kurgulardan biri de yerleşke yapılarında görülen kümeleşme durumudur. Öğrencilerin kalacağı yerler ellişer ya da en çok yüzer kişilik kümeler için etüt ve yemek odasını, mutfağını, küme öğretmeninin konutunu da içine alan birimler olarak düşünülmüştür. Bu doğrultuda 40-50 kişilik kümler için çalışma, dinlenme ve barınma alanları ayrılmış yerleşim düzeni oluşturulmuştur. Enstitüler için açılan tasarlanan projelerin kampüs niteliğinde olduğu ve tümünün modern birer köy örneğinde olduğu da söylenebilir (Şimşek ve Mercanoğlu, 2018: 269).

Köy enstitüleri yerleşkelerinin tasarımı için ilk aşama olarak 1940 yılında on iki adet Enstitü için ulusal mimari yarışması açılmıştır. 1941 yılında Ankara Hasaoğlan, 1943'te Sivas 
Yıldızeli ve Konya İvriz Köy enstitüsü olmak üzere toplamda on beş adet Köy Enstitüsü yarışma projesi kapsamında tasarlanmıştır. Cılavuz, Dicle, Ernis, Kızılçull ve Ortaklar Köy Enstitüsü için yarışma açılmamıştır. Ortaklar Köy Enstitüsünün proje üretimi ise Hasanoğlan Yüksek Köy Enstitüsü yapı kolunun başında görev alan Y. Mimar Muallla Eyüboğlu tarafından gerçekleşmiştir (Keskin, 2012: 111-135).

Enstitülerin eğitim programındaki dersler kültür dersleri (matematik, resim vb.), teknik dersler (demircilik, dikiş-nakış, tuğlacılık vb.), ziraat dersleri (bahçecilik, arıcılık vb.) olmak üzere üç ana grupta toplanmıştır. Yapıcılık dersleri kapsamında verilen dülgerlik, duvarcılık eğitimlerinin yanında betonculuk eğitimin de verilmesi dönemin mimarlık ortamıyla paralellik göstermektedir. $\mathrm{Bu}$ durum kırsal kesimde yöreye özgü malzeme kullanımı ağırlıkta olsa da modern mimarinin vazgeçilmezi olan beton hakkında da bilgi sahibi olduğunu göstermektedir.

\section{ORTAKLAR KÖY ENSTITÜSÜ}

Ortaklar Köy Enstitüsü, 16 Ağustos 1944 tarihinde Aydın'ın Ortaklar bucağına 2,2km. uzaklıkta Adabelen Tepesi olarak adlandırılan yerde kurulmuştur. Enstitü 1945-1946 EğitimÖğretim yılında Kızılçullu Köy Enstitüsü’nden gelen; Aydın ve çevresi doğumlu öğrencilerle eğitim ve öğretim hayatına başlamıştır. Kurucu müdür Hayri Çakalöz'dür (Url-1). Okul giriş kapısından başlayıp okul ana binasına ulaşan yol, asfaltla kaplı, iki yanı ağaçlıklıdır. Yolun her iki tarafında Adabelen Ortaokulu, erkek ve kız yurtları, yemekhane, kantin ve lojmanlar bulunmaktadır. Lojmanlar tek katlı, müstakil, bahçeli konut biçimindedir. Apartman biçimindeki lojmanlarda 20 adet daire bulunmaktadır ve bunlar sonradan ilave edilmişlerdir. Okul bu haliyle tam bir yerleşke görünümü arz etmektedir. Bu yerleşkede 7 adet bina vardır. Bunların dişında Köy Enstitüsü'den kalma 30 adet bina bulunmaktadır ki bunlar, İzmir Tabiat Varlıklarını Koruma Kurumu'nca koruma altına alınmıştır. Enstitü birinci derecede "sit alanıdır". Okul ana binasının güney ve kuzey bahçeleri bulunur. Güney bahçesinde futbol sahası ve meyve bahçesi vardır. (Url-2).

Şekil 1. Yerleşim düzeni

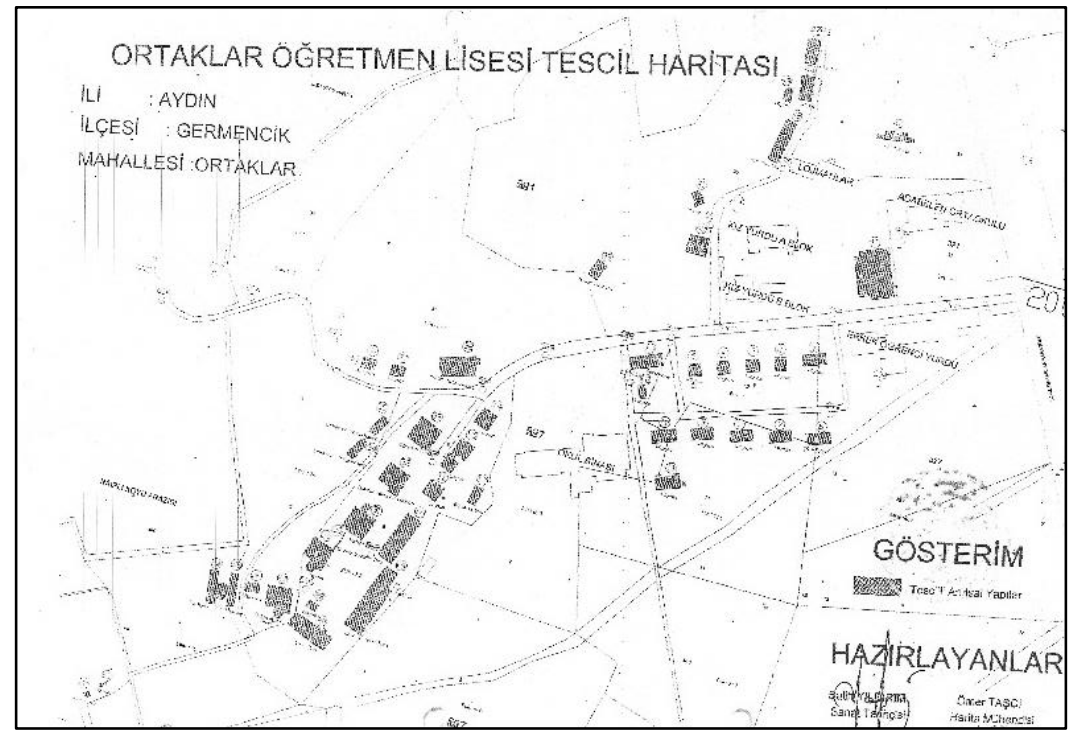

Kaynak: Ortaklar Fen Lisesi Arşivi

Ortaklar Köy Enstitüsü de diğer enstitülerin vaziyet yerleşimlerindeki temel yaklaşımlara sahiptir. Eğitim ve uygulamanın bir arada gerçekleştirilmesi ilkesi, Enstitülerin mekânsal organizasyonunun birincil belirleyicisidir (Hovardaoğlu, 2014: 586). Ortaklar Köy Enstitüsü de idari bölüm, eğitim ve uygulama bölümleri, sosyal, kültürel ve barınma işlevli yapılar bütününün yer aldığı kısım yerleşke bölümünü oluştururken, tarımsal faaliyetlerin gerçekleştirildiği kısım uygulama bölümünü oluşturmaktadır. Kendisine tahsisli 682.685 
metrekare arazi üzerinde kurulu olan Ortaklar Köy Enstitüsünün 1840 dekar arazisi üzerinde yerleşkeyi oluşturan yapılar bulunmakta, geri kalan sahalar ise tarımsal faaliyetlere ayrılmış durumdadır. Kuzey tarafinda, Adabelen Tepesi'nin eteklerine kadar olan kısımda, geniş bir çam koruluğu bulunur. Enstitü çam ağaçlarının dışında, yüzlerce meyve ağacı ve palmiyeleriyle eşsiz bir görünüme sahiptir (Url-2).

Şekil 2. Enstitünün ilk binaları

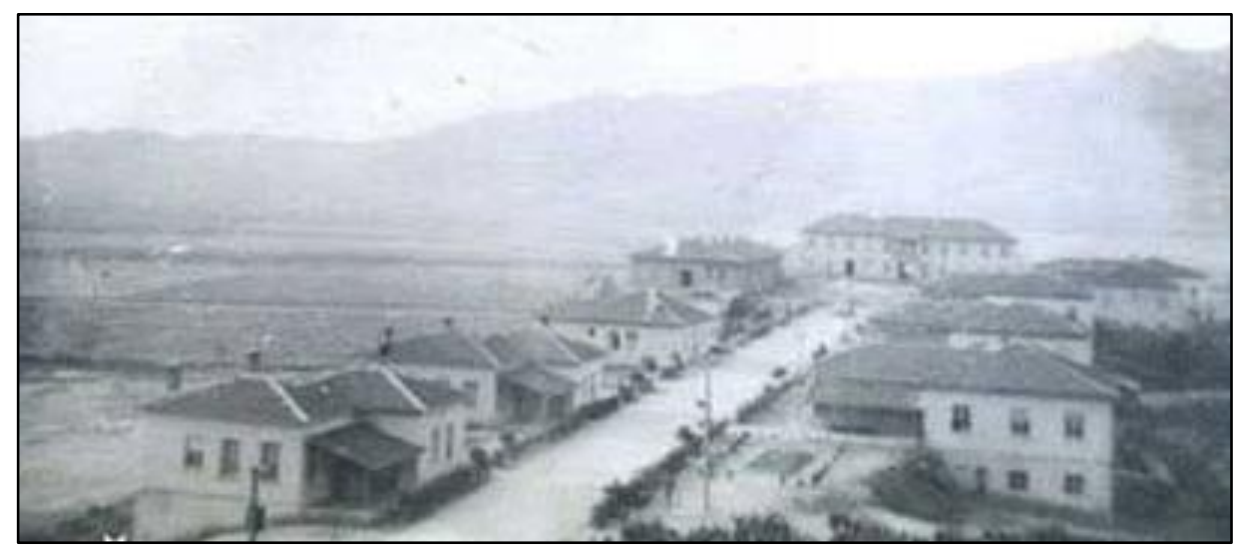

Kaynak: Url-3

Enstitüde ilk inşa edilen ana yapılar derslikler ve uygulama sınıfları, öğretmenler için lojmanlar, öğrenciler için yatakhane ve yemekhaneden oluşmaktadır. Zaman içerisinde idari bina, revir, kütüphane, atölyeler, derslik binası, öğrenci lokali, hamam, kantin, spor salonu da eklenmiştir. Enstitü bünyesindeki yapıların geneli 1-2 katlı, yerel malzeme kullanılarak ve Kızılçullu'dan getirilen 300-400 öğrenciden oluşan yapıcı ekibin iş gücüne dayalı olarak inşa edilmiştir. Enstitüler arası yardımlaşma ile başlayan ilk inşa sürecinden sonra zamanla eklenen yeni yapılarla birlikte toplamda yaklaşık 30 adet yapıdan oluşan yerleşkeye dönüşmüştür. Yerleşkenin arazi planında ana yapıların yoğunluğu kuzeydoğu yönündeki ana aks üzerindedir. Aksın doğusunda kalan alanda öğretmenler için yapılan tek ve iki kattan oluşan lojmanlar yer almış tam karşısına ise derslik ve uygulama sınıfları ile birlikte öğrenciler için yemekhane ve yatakhane olarak hizmet veren yapılar inşa edilmiştir. Enstitünün inşa süreci devam ettikçe aksın sonunu oluşturan güneybatı ucuna iki katlı idari bina yapılmış ve önünde küçük bir süs havuzu ile peyzaj düzenlemesinin yapıldığı meydan yer almaktadır. Film gösterimleri için beyaz duvarının bulunduğu ve tören alanı olarak da kullanılan bu meydan yerleşkenin kültürel ve günlük yaşantısıyla da bütünleşmiştir. $\mathrm{Bu}$ meydan günümüzde de farklı etkinliklerde kullanılmaya devam etmektedir.

Şekil 3. İdari binanın önündeki meydan görünüşü

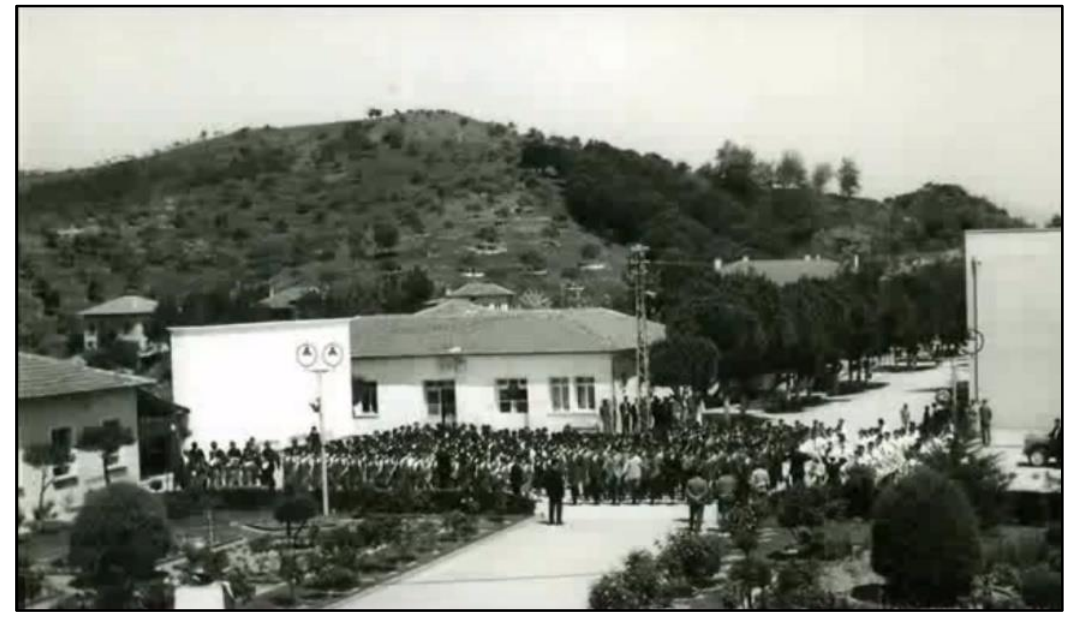

Kaynak: Url-3 
Enstitü yerleşkesindeki idari bina, derslikler ve yatma birimlerinin sıralandığ 1 kuzeydoğu aksına bakıldığında hissedilebilir güçlü bir geometrik düzen hâkimdir. Bu rasyonel yerleşimde benzer ve tekrar eden kütleler arasında bırakılan boşluklar, yapı-açık alan ilişkisinde denge sağlamaktadır. Enstitülerin mimarilerine hâkim olan parçalı ve çevresiyle bütünleşik tasarım yaklaşımı Ortaklar Köy Enstitüsünde de okunmaktadır. Fakat günümüzde eklenen yapılara bakıldığında bu anlayıştan uzak tek hacimden oluşan büyük yapı kütleleri bulunmaktadır. Enstitüye ait çoğu yapı günümüzde halen ayaktadır. İzmir Tabiat Varlıklarını Koruma Kurumu'nca koruma altına alınmıştır. Enstitü birinci derecede "sit alanıdır" Kimi binalarına restorasyon yapılarak yeniden işlev (tiyatro ve gösteri salonu olarak) verilmiş olsa da çoğu yapısı âtıl durumda beklemektedir.

\section{MIMARİ BICÇIMLENME}

Cumhuriyet sonrasının mimarlık ortamında hâkim olan modernizm anlayışı, mimaride rasyonel bir değişime neden olmuştur. Bu doğrultuda mimarlık ortamının değişen form ve biçimleri Avrupa'da etkin olan Bauhaus fikirlerinin etkisiyle ortaya çıkmıştır. Gropius'un ilkelerinden basit geometrik formlardan oluşan tasarımlar, şerit pencereler ile doğaya hâkim olma isteği, geniş cam yüzeyler ile iç-dış mekân arasında kurulan görsel ilişki, mekan düzeninde fonksiyonellik ve beyaz dış cephe gibi unsurlar, bu anlayışın belirgin özelliklerini oluşturmuş̧tur (Ozan, 2009, s.48). Küp, prizma, daire gibi prizmatik hacimlerden oluşan geometrik ve soyut kompozisyonlardan oluşan biçimler halk dilinde ' kübik mimarlık' olarak tanımlanmıştır. Kübik mimari yeni ihtiyaçların zorunlu bir sonucu olarak görülerek dönemin tipik geometrik biçimlerinin güzelliği ve gerekliliği bilimsel pozitivist açıklamalarla açıklanmıştır. Tasarımda işlevselci ve rasyonalist tutumlar mimarlığın ana söylemlerinden biri haline gelmiştir (Bozdoğan, 2001:188).

Modernist anlayışın estetik söyleminde yalın cepheler, saf geometriler, tasarımda sadelik, işlevsellik ve rasyonellik kavramları oldukça fazla yer almaktadır. Modernleşme misyonuyla birlikte Erken Cumhuriyet döneminde kiremitli çatılar, çatı saçakları, detaylarla süslü cepheler, simetrik biçimlenmeler yerini düz teras çatılara, sade cephelere ve asimetrik kompozisyonlara bırakmıştır. Malzeme olarak beton, çelik ve cam kullanımı kütlesel olarak da kübik formlar ve geometrik şekiller ön plana çıkmıştır. Tüm bu özellikler başta konut olmak üzere kamu yapılarında da kendini göstermiştir.

Sayar ' 'Mektep Binalarında Estetik', başlıklı yazısında okullarının modern olmasını teknik ve rasyonel olarak açıklamıştır. Okul binalarının yeterli ışık ve hava almasının gerekliliğinden, sıhhi olmasından dolayısıyla toz tutmaya müsaade etmeyen düz yüzeylere sahip olan bu basit ve sade bir okul mimarisinden bahsetmektedir. Bunların armonisiyle devamlı, asil ve güzel bir mimarinin mümkün olacağını söyler (Sayar, 1931:254).

1944 yılında yapımına başlanılan Ortaklar Köy Enstitüsünde Mimar Mualla Eyüboğlu tarafından tasarlanmış olan derslik binası sahip olduğu cephe özellikleri, yapı malzemesi, yapı ve çatı konstrüksiyonu gibi mimari özellikleriyle yerleşke içerisindeki diğer yapılardan net bir şekilde ayırt edilebilmektedir. Modernist anlayışın yerini II.ulusal mimarlık akımının aldığı bir dönemde tasarlanmasına rağmen belirgin biçimde modernist estetiğe sahiptir. Yapı yekpare dikdörtgen bir kütleden meydana gelir. Kübik mimarinin karakteristik özelliklerinden olan düz teras çatısıyla, asimetrik kompozisyona sahip cephesiyle ve yalın geometrisiyle Bauhaus estetiğini de taşımaktadır. Yerleşke içerisindeki betonarme iskelet sistemine sahip olan tek binadır. Bu durum yapının cephe düzenlenmesine esneklik imkânı vermiş ve büyük cam yüzeyler kullanılmıştır. 
Şekil 4. Derslikler ön ve arka cephesinden görünüm

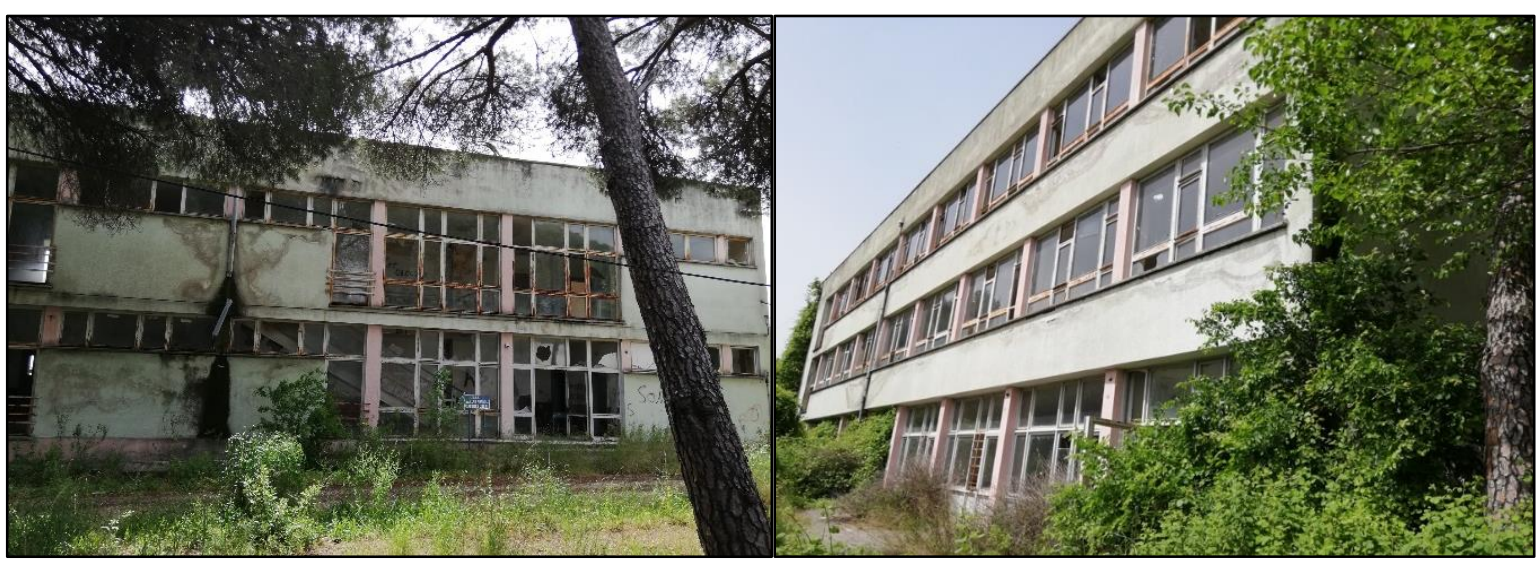

Kaynak: Kıran,2019

Yerleşke meydanıyla da ilişki içerisinde olan bina eğime paralel oturtularak araziye kuzeydoğu-güneybatı aksında yerleşmiştir. Toplam üç kat yüksekliğine sahip olan yapının bir katı araziye gömülmüştür. Meydana giden aksa paralel olan giriş cephesi asimetrik düzende olup yatay pencereler ve geniş cam yüzeylerden meydana gelmektedir. Cephe boyunca uzanan ince şerit pencereler yatayda güçlü bir etki oluştururken kimi yerde yere kadar uzanan dik pencerelerle bölünmüş, giriş bölümünde ise geniş pencereler kullanılmıştır. Arka cephede de asimetrik cepheye sahip yapı strüktürel sistemin arasında geniş cam yüzeylerden oluşur. $\mathrm{Bu}$ cephede yer alan derslikler olabildiğince doğal ışıktan faydalanmıştır. Derslikleri boydan boya geçen geniş büyük pencereler yapının şeffaflığını ve dışarıya açık karakterini vurgulamaktadır.

Şekil 5. Sınıflara ve koridora ait iç mekân görselleri

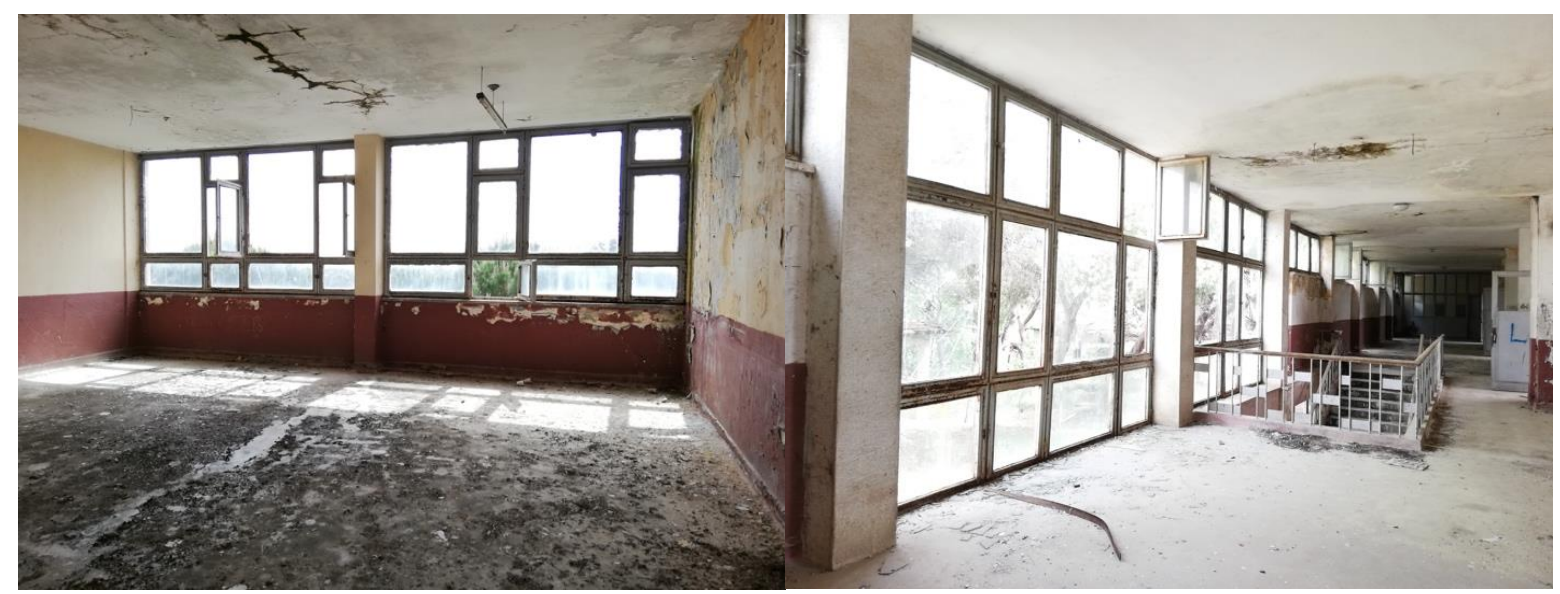

Kaynak: Kıran,2019

Yapının tek koridorlu plan sisteminde, güneye bakan eşit büyüklükteki tüm sınıflar koridor boyunca sıralanmıştır. Ön cepheye yaslanmış tek kollu merdivenin yer aldığ 1 geniş koridor boyunca yataydaki sürekli pencereler ve yere kadar uzanmış büyük pencereler sayesinde oldukça ferahtır. Birinci ve ikinci katta koridorun bir ucunda servis mekânları yer alırken diğer ucu da camla bölünmüş bir mekâna açılmaktadır. Bodrum katının koridor cephesinin eğime oturması nedeniyle eksik kalan doğal aydınlatma sınıfların koridor duvarlarında açılan yatay pencerelerle gerçekleştirilmiştir. Ayrıca merdivenin çıkış noktasından dışarıya açılan ikinci bir koridor da ana koridora bağlanarak hem aydınlatma hem de havalandırması gerçekleştirilmiştir. 
Şekil 6. Derslik binasının zemin ve birinci kat planları
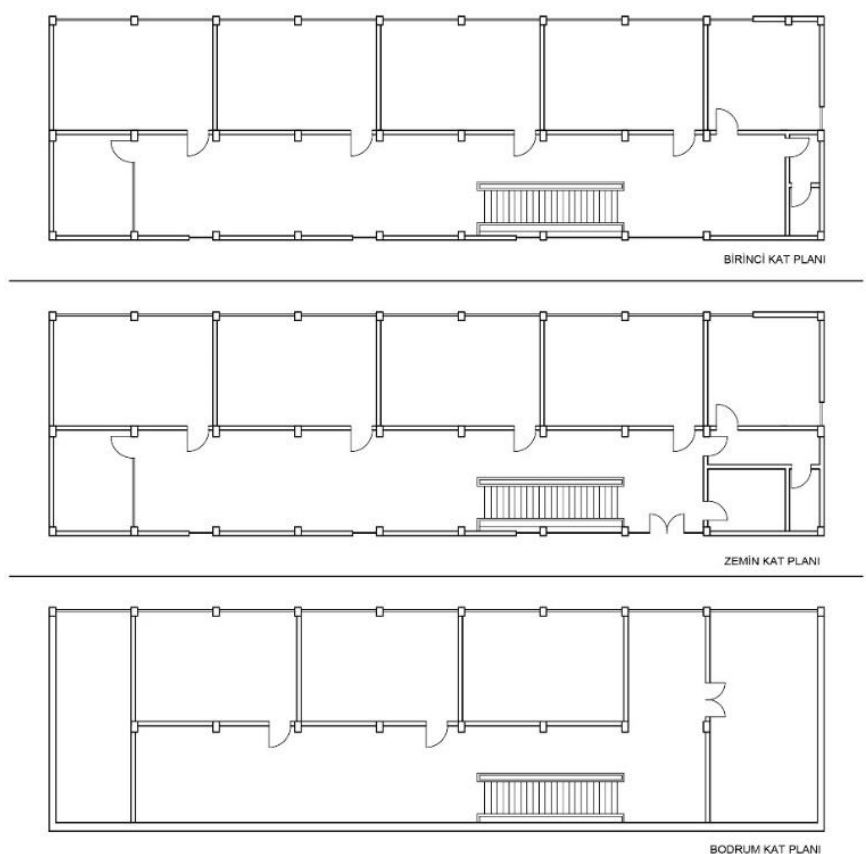

Yerleşkede Mualla Eyüboğlu tarafından tasarlanan bir diğer yapı da Resim-Müzik atölyesi binasıdır. Modern eğitim vizyonuna sahip enstitülerde sanat eğitimiyle birlikte öğrencilere resim-elişleri, müzik, tiyatro, el sanatları gibi dersler verilmiştir. Enstitünün modern ilişkilere yönelik sosyal ve kültürel faaliyetlerin gerçekleștirildiği bu mekânlar bütünü kültürel yaşantıda önemli olduğu gibi yapısal olarak da önemlidir. Ortaklar enstitüsündeki resim-müzik atölyesinin kütle biçimlenişinde de yine modern izler taşımaktadır. Yapı yalın geometrilerin birleşiminden oluşur. Kütle dik açllardan oluşan dikdörtgen hacimlere eklenen yarım daire formundan oluşmuştur. Yapının silindirik uzantısındaki çatının çıkıntılı bitişi, şerit halindeki sürekli pencere denizlikleri ve kat çizgisindeki çıkıntılı bordür ile yatay etki arttırılmıştır. Erken Cumhuriyet döneminde kentlerde konuttan kamusal alana kadar birçok yapıda yuvarlak köşeler ve formlar düz teras çatılı kübik hacimlerden oluşan kompozisyonlarla kullanılmıştır. Tek cephesinde kullanılan bu belirgin form modernliğin en belirgin ve yaygın estetik simgelerinden biridir (Bozdoğan, 2001, s.254). Kırsal alanda sı1k karşılaşılmayan daire formu modern biçimlerin kırdaki yorumunu oluşturmuştur. Modern biçimler geleneksel yöntemlerle birleştirilmiştir.

Şekil 7. Resim ve Müzik Atölyesi

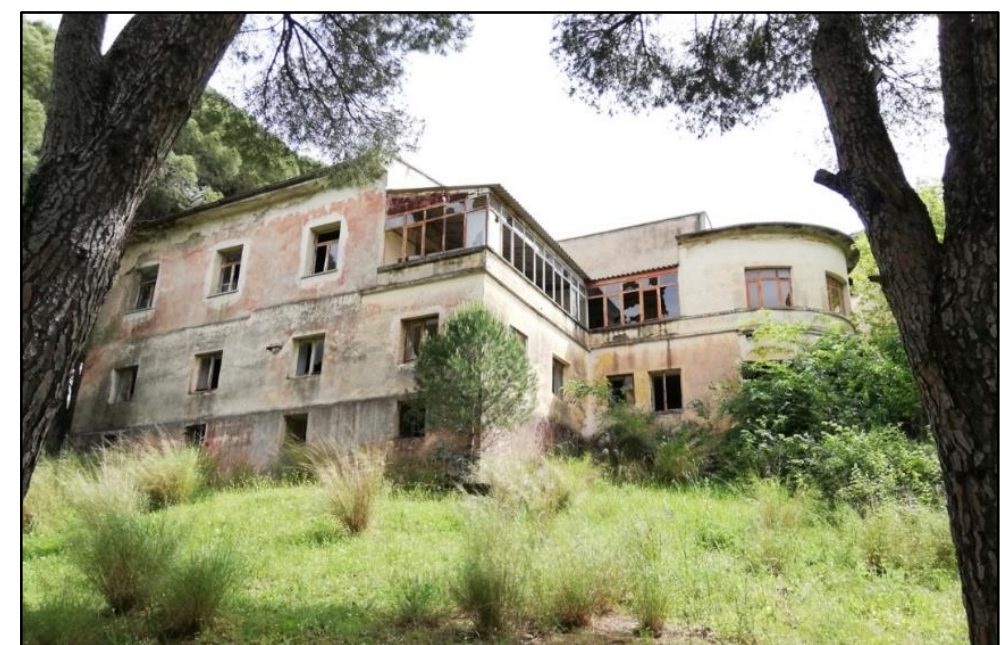

Kaynak: Kıran,2019 
Yerleşke genelindeki yapılar tek ve iki kattan oluşurken derslik binalarında kat yüksekliği üçe çıkmıştır. Yerleşkenin kümeleşme düzeninde lojmanlara ayrılan alandaki yapılar dikdörtgen ve kare formunda olup tamamı tek katlıdır. Yapılardaki malzeme kullanımı diğer enstitülerle benzerlik göstermekte olup genelinde yerel malzeme tercih edilmiştir. Taş, tuğla ve ahşap malzemelerle imece usulü inşa edilmiştir. Ekonomik koşullar, bölgeye uygunluk ve kolaylığı nedeniyle tercih edilen yerel malzeme ve inşa teknikleri kullanılmıştır. Enstitü binalarının çoğunluğunu oluşturan bu yapıların çatıları ise ahşap konstrüksiyonlu kırma ya da beşik çatı biçiminde yapılmış ve kiremitle kapatılmıştır.

Şekil 8. Lojmanlar
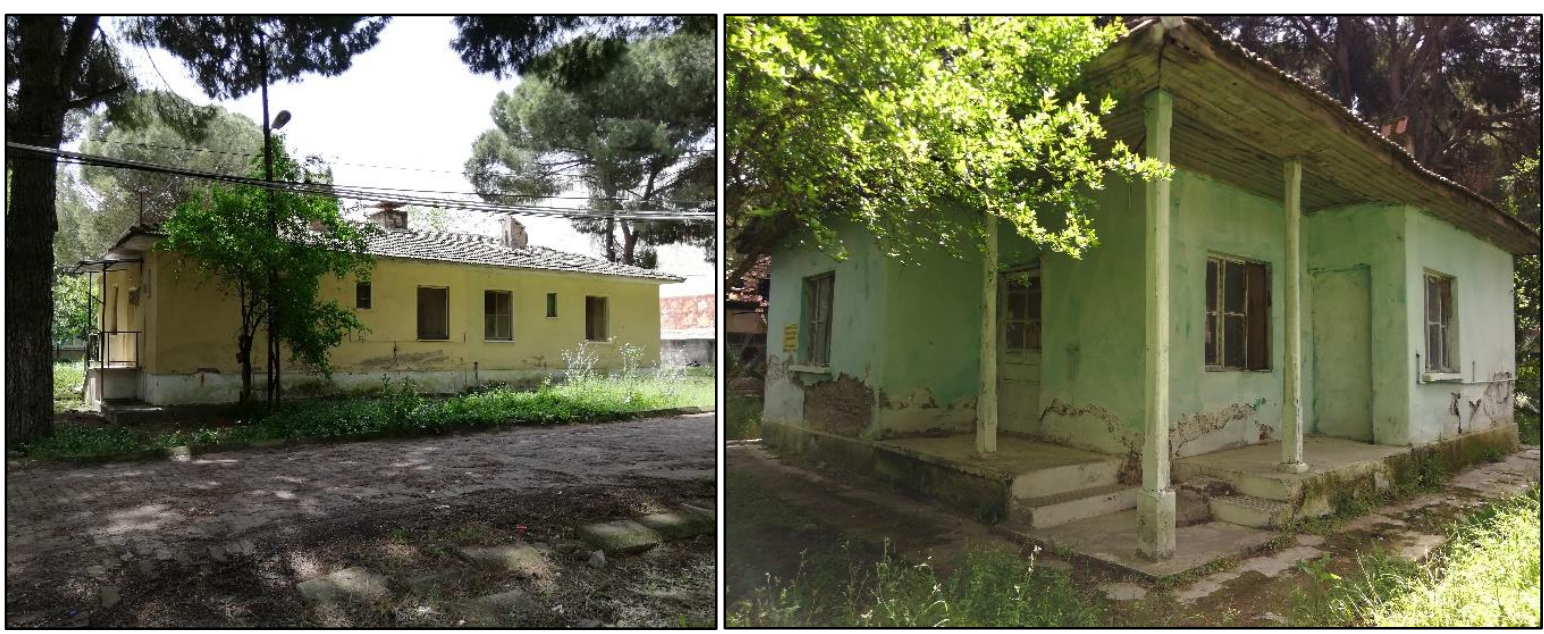

Kaynak: Kıran, 2019

Adabelen Tepesi'nin üst noktasında yer alan simetrik cephe anlayışına sahip idari binanın ortasında üç basamaktan oluşan üç taraflı bir giriş merdiveni bulunmaktadır. Yapının meydana bakan ön cephesindeki bu girişin iki yanında yükselen kolonların üstünde yer alan bir balkon (hitap balkonu) bulunmaktadır. Arka cephesi de aynı tasarım anlayışına sahip olmakla birlikte zemin ve birinci katındaki tuğla kolonlarla geçilen ve neredeyse cephe boyunca devam eden balkon açıklıkları bulunmaktadır. Benzer cephe özellikleri revirde de görülmektedir. İki katlı inşa edilmiş olan revirin cephesinde yine ahşap kolonlarla sağlanmış yarı açık mekânlar, Enstitü genelindeki diğer genel cephe özelliklerine göre farklı tasarlanmışlardır.

Şekil 9. İdari Bina-solda, Revir-sağda (ön cepheler)

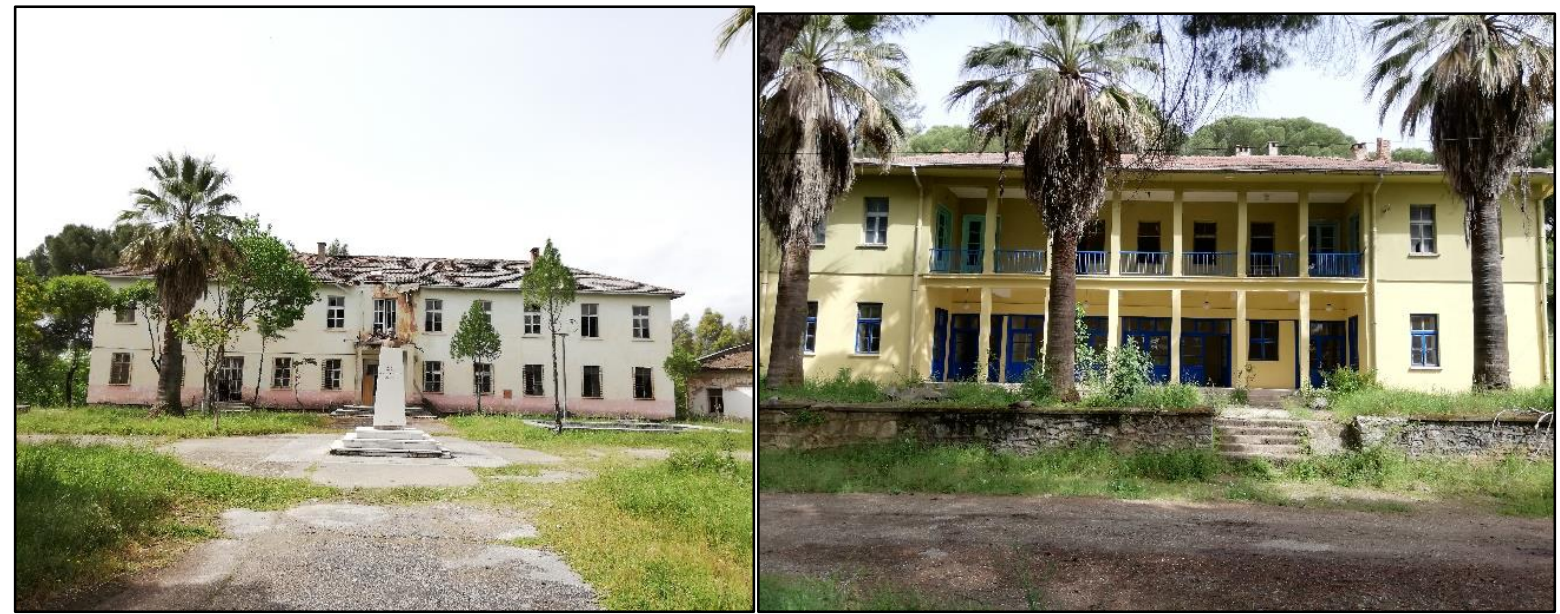

Kaynak: Kıran, 2019 
Şekil 10. Öğrenci yatakhanesi-sol ve Öğrenci lokali-sağ

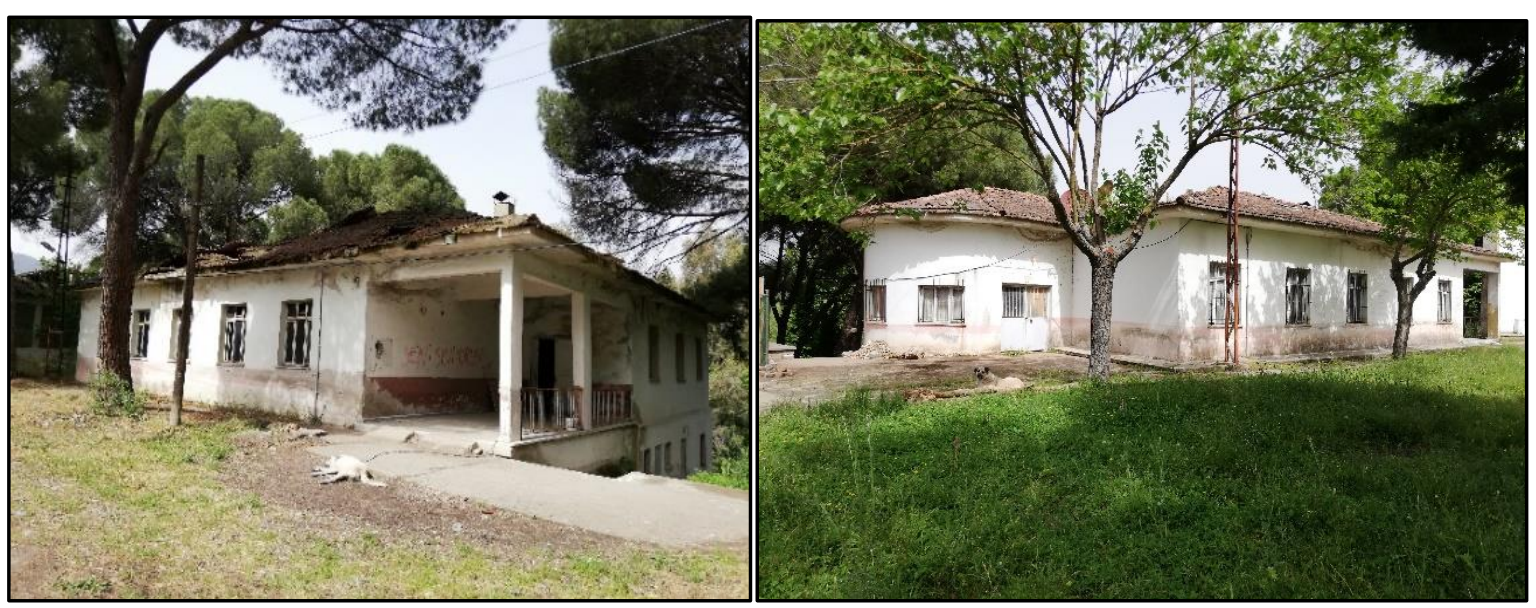

Kaynak: Kıran, 2019

\section{SONUÇ}

1940 yılından 1954 yılına kadar olan kısa bir zaman dilimi içerisinde uygulanma fırsatı bulan Köy Enstitüleri'nin etkisi uzun olmuş bıraktığı izlerle günümüzde de tartışılmaya devam edilmiştir. Cumhuriyet döneminin önemli eğitim politikalarından biri olup, Cumhuriyet'in amacına uygun olarak çağdaşlaşmak ön planda tutulmuştur. Enstitüler, eğitimlerinde modern ilkeleri benimsemiş ve bu ilkeler doğrultusunda kırsal alanı da kalkındırmayı hedeflemiş özgün kurumsal yapılardır. Köy Enstitüleri modern ve yerel arasında bilgi, akış, biçim ve boyuttaki dönüşümleri; modernin kırsalda nasıl evrildiğini görme olanağı sağlamaktadır (Çetin ve Kahya, 2017:161). Enstitüler dönemin modernleşme ruhunu sadece sahip oldukları eğitim vizyonuyla değil, kuruluş aşamasındaki açılan yarışmalar ve mimari üretimlerinde de sergilenen rasyonel ve akılcı yaklaşımlarla da göstermiştir.

Enstitülerin modern düşünce sistemiyle yerel imkânlar birleştirerek bir bütün oluşturulmuş ve ortaya özgün mimari değerler çıkmıştır. Anadolu'nun 21 bölgesinde kurulan her bir enstitü aynı kuruluş ilkeleriyle yere özgü olarak şekillenmiş aklı ve işlevi ön planda tutarak yerleşkelerini kurmuştur. Modernleşmenin rasyonel örgütlenme güdüsü enstitülerin eğitim vizyonundan, yerleşme planlarına ve mimari tasarımlarına kadar birçok noktada etkilemiştir. Bu bakımdan enstitülerin kuruluşunda Bauhaus düşüncesinin pedogojik ve estetik değerlerinin yansımalarını bulmak mümkündür. Eğitim ve yaşamın birlikte sürdürüldüğü yerleşke içerisinde çağın inşa tekniklerinin uygulandığı ve mekânsal organizasyonun ve kütlesel biçimlenişin rasyonel ilkelere dayandığı tasarımlar uygulanmıştır. Ortaklar Köy Enstitüsü'nün bu bakımdan önemli iki yapısı günümüze kadar gelerek enstitü içerisindeki farklı mimari karakteristik özellikleriyle modern düşüncenin yereldeki somut ve belirgin yansımaları olarak karşımıza çıkmaktadır.

Ortaklar Köy Enstitüsünün günümüzdeki yapılarının çürümeye terk edilmiş olması mimarlık açısından önemli bir kayıptır. Enstitü yerleşkesindeki doğa ve yapı ilişkisinin ön planda tutulduğu insancıl yaklaşımla oluşturulan düzenin, yerel malzemelerle yalın ve sade bir mimari anlayışa sahip enstitü yapılarının bir bütün olarak değerlendirilmesi ve mimarlık alanına geri kazandırılması gerekmektedir. Özellikle Ortaklar Köy Enstitüsünün sahip olduğu iki ana binasındaki modern mimarlığın belirgin izlerini taşıyan yapılar Cumhuriyet döneminin mimari anlayışının kırdaki yansımalarını göstermesi bakımından da önemli bulunmaktadır. Geleneksel ile modernin bir arada yer aldığı bir deneyim alanı olan enstitüler bünyesindeki mimari yapılar ile bu birlikteliğin özgün ve somut bir gösterimi olmuşlardır. 
Şekil 11. Enstitünün günümüzdeki durumu genel görünüm

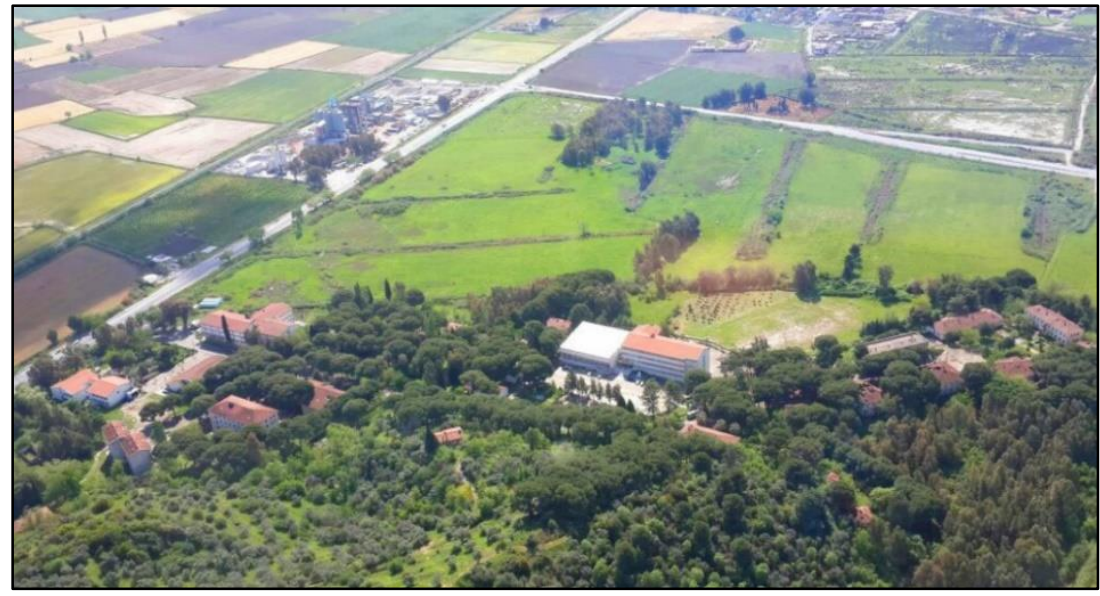

Kaynak: Url-4

\section{KAYNAKÇA}

AKÖZER, E., 2009. Mimarın Özgürlüğü, Bauhaus: Modernleşmenin Tasarımı/Türkiye'de Mimarlık, Sanat, Tasarım Eğitimi ve Bauhaus, der. A. Artun\&E. Aliçavuşoğlu, İletişim Yayınları, İstanbul: 11-121.

ARTUN, A. 2009. Geometrik Modernlik: Bauhaus Enternasyonali ve Türkiye'de Sanat, Bauhaus: Modernleşmenin Tasarımı/Türkiye'de Mimarlı, Sanat, Tasarım Eğitimi ve Bauhaus, der. A. Artun\&E. Aliçavuşoğlu, İletişim Yayınları, İstanbul: 183-93

ATLIHAN, Ş., 2009. Cumhuriyetten 1970'li Yıllara Kadar Öğretmen Okullarındaki Sanat Eğitiminde Bauhaus Benzeri Uygulamalar, Bauhaus: Modernleşmenin Tasarımı/Türkiye'de Mimarlı, Sanat, Tasarım Eğitimi ve Bauhaus, der. A. Artun\&E. Aliçavuşoğlu, İletişim Yayınları, İstanbul:451-482.

BOZDOĞAN, S., 2001, Modernizm ve Ulusun İnşası: Erken Cumhuriyet Döneminde Ulusun Inşasl, Metis, İstanbul.

ÇALIŞIR HOVARDAOĞLU, S., 2014, Pazarören Köy Enstitüsü’nün Sosyo-Mekânsal Etkilerinin Değerlendirilmesi Üzerine Bir Kırsal Tarih Araştırması (1938-1954), Tarih Okulu Dergisi, 19, 581-599.

ÇETIN, S., KAHYA, A., 2017, Kırda Bir Modernleşme Projesi Olarak Köy Enstitüleri: Aksu ve Gönen Örnekleri Üzerinden Yeni Bir Anlamlandırma Denemesi, METU, 34:1, 133162.

KESKİN, Y., 1998, Cumhuriyetin 75. Y1ldönümünde Devrim Mimarisi Olarak Köy Enstitülerine "Resmi Geçit", Mimarlık, 248, 8-15.

KESKIN, Y.,2012, Köy Enstitüleri İçin Açılan Mimari Proje Yarışması, Düşünen Tohum, Konuşan Toprak, Cumhuriyetin Köy Enstitüleri 1940- 1946, İstanbul Araştırmaları Enstitüsü Yayınları 18, Sergi Katalogları 10(C.2) 111-35. 
KÖKSAL, D. 2009. Cumhuriyet İdeolojisi ve Estetik Modernizm: Baltacığlu, Yeni Zamanlar ve Bauhaus, Bauhaus: Modernleşmenin Tasarımı/Türkiye'de Mimarlık, Sanat, Tasarım Eğitimi ve Bauhaus, der. A. Artun\&E. Aliçavuşoğlu, İletişim Yayınları, İstanbul: 241261.

OZAN, M., 2009. Bauhaus Okulu ve Erken Cumhuriyet Dönemi Mimarisi- İç Mimarisine Etkileri.Yüksek Lisans Tezi, Yıldız Teknik Üniversitesi.

TÜRKOĞLU, P., 2000, Tonguç ve Enstitüleri, Türkiye İş Bankası Kültür Yayınları, İstanbul.

SAYAR, Z., 1931. Mektep Binalarında Estetik, Arkitekt, 8, 253-254.

ŞİMŞEK, G., MERCANOĞLU, C., 2018, Bir “Planlama Örneği” Olarak Köy Enstitüleri Deneyimi, Planning, 28(3): 261-281.

YILMAZ, N.Y., AKANDERE, O., 2018, Köy Enstitülerinin İdeolojik Yapısı, Çăgdaş Türkiye Tarihi Araştırmaları Dergisi, 35(17): 275-316.

\section{Internet Kaynakları}

Url-1: http://ofl.meb.k12.tr/meb iys dosyalar/09/05/757853/icerikler/okulumuzun-tarihcesi 1755031.html [Erişim Tarihi: 12 Mayıs 2019]

Url-2: http://ofl.meb.k12.tr/meb_iys_dosyalar/09/05/757853/icerikler/kampusalani_2446684 .html [Erişim Tarihi: 12 Mayıs 2019]

Url-3: http://www.adabelenlilerdernegi.com [Erişim Tarihi: 12 Mayis 2019]

Url-4: http://ofl.meb.k12.tr/meb_iys_dosyalar/09/05/757853/icerikler/kampusalani_2446684 \%20.html [Erişim Tarihi: 12 Mayıs 2019]

\section{NOTLAR}

\footnotetext{
${ }^{1}$ Mualla Eyüboğlu Anhegger Devlet Güzel Sanatlar Akademisinden mezun olan Türkiye’nin ilk kadın mimarlarındandır. İnşa ettiği modern yapılar gerçekleştirdiği eski yapı restorasyonları gibi mimarlığın çeşitli alanlarında çalışmış olan mimar bunun yanında eğitmenlik de yapmıştır. Yapı Kolu Başkanı ve Enstitü Yüksek Bölümü inşaat öğretmeni olarak çalıştı̆̆ dönemde köy enstitülerinde hem teorik hem de uygulamalı dersler vermiştir. Köy Enstitüleri bağlamında Edirne'den Kars'a kadar ülkenin dört bir yanına giderek hem üretmiş hem inşa etmiş hem de eğitmiştir. Ayrıca enstitü ve köy okulu inşaatlarının kontrollügünü yapmıştır. Mesleğin farklı alanlarında etkin olan mimar çok yönlü çalışmalarıyla Cumhuriyet döneminin üretken mimarlarından biri olmuştur.
} 